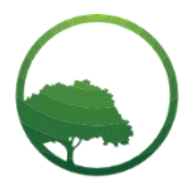

Research in Business \& Social Science

IJRBS VOL 10 NO 6 ISSN: 2147-4478

\title{
Selling price according to traditional traders in the practice of Jual Kase-Kase
}

\author{
(D) Melati Sukma Dewi Labusang ${ }^{(a)}$ (iD) Iwan Triyuwono ${ }^{(b)}$ (D) Bambang Hariadi ${ }^{(c)}$ \\ ${ }^{(a, b, c)}$ Faculty of Economics and Business, Brawijaya University, Malang, Indonesia
}

A R T I C L E I N F O
Article history:
Received 18 August 2021
Received in rev. form 17 Sep. 2021
Accepted 19 Sept 2021
Keywords:
Price, Traditional Traders, Jual Kase-
Kase
JEL Classification:
O15

\begin{abstract}
A B S T R A C T
Jual kase-kase is a selling practice by traditional Banggai traders. Jual Kase-Kase is a term that comes from a habit of traders, thus making people call their practice the term Jual Kase-Kase. Starting from the barter system or the exchange of goods sold from house to house by traders, thus forming a way of transacting based on interests. In making an exchange the traders voluntarily accept the imbalance provided by the buyer. Changes in the sales system, affect the way of trading carried out by traditional traders, assigning value to each item sold and changing the location of the seller has an influence on the traders. However, the character of traditional traders is not lost even though some things from their sales practices have changed. The value given to an item does not only seek material benefits for traders but includes non-material values. Jual Kase-Kase means to give excess voluntarily. The purpose of this research is to reveal the meaning of selling price in the practice of selling cases from the perspective of traditional traders. An ethnomethodological approach is used to understand the meaning of the selling price of the practice of Jual Kase-Kase carried out by traditional traders. In this study, the value of goods sold by traditional traders is influenced by Banggai culture which is inherent in the character of traditional traders, where the value of goods is not only formed from material values but is formed from social and spiritual values. Where the social value is seen in the relationship created between fellow sellers or between sellers and buyers. The spiritual value that is present in the determination of the selling price is seen in the sincerity, honesty, and inner feeling of the perpetrator which finally appears in the price given.
\end{abstract}

(C) 2021 by the authors. Licensee SSBFNET, Istanbul, Turkey. This article is an open access article distributed under the terms and conditions of the Creative Commons Attribution (CC BY) license (http://creativecommons.org/licenses/by/4.0/).

\section{Introduction}

Price in sales activity is the main factor as a buyer's attraction. The price contained in a product will also determine the amount of profit that will be obtained by the seller, so the seller is very concerned in determining the price. At first, the system of barter (exchanging goods) before the existence of money. In this system there are two interests who want to have, then there is an exchange of goods according to need. This creates a voluntary agreement between the two parties. However, in its development this system resulted in injustice, because the value of the goods sold did not match the value of the goods purchased.

Sardjono $(2017 ; 63)$ explains that price is the value of goods or services in nominal money. In addition, prices have an influence on market behavior where the law of supply and demand applies, as well as the presence of producers and consumers (Winardi, 1987:12; Sardjono 2017:63-64). This means that economic activities arising from buying and selling are oriented towards meeting the needs of the perpetrators. Sellers and buyers are market participants who are part of forming prices. Bargaining is an interaction created by sellers and buyers to make a price agreement and fulfill their needs.

Modern accounting has provided several methods of setting selling prices. Cost-based pricing such as cost-plus pricing, markup s and target costing (Akbarina. 2018; Hardesty et al. 2012; Mulyadi 2001; Witjaksono. 2013), and customer-based pricing (Pellinen. 2003; Hinterhuber. 2008; Benito et al. 2010). The selling price presented by modern accounting which is highly oriented to the numbers obtained from business activities leads to the profits earned. These methods see an economic reality that is only seen from one point

* Corresponding author. ORCID ID: 0000-0002-0913-1168

(C) 2021 by the authors. Hosting by SSBFNET. Peer review under responsibility of Center for Strategic Studies in Business and Finance.

https://doi.org/10.20525/ijrbs.v10i6.1350 
of view, namely profit maximization. With this perspective will produce the value of egoism. Accounting is a discipline and practice that is influenced by its environment, after accounting is influenced, accounting again affects the environment (Triyuwono, 2015). Therefore, when accounting grows in a capitalist environment, the values in accounting will also be capitalist. As a result, the network of capitalist power shackles humans to always practice it.

When the selling price is only based on achieving maximum profit, there will be a separation between the material and non-material aspects that surround it. Mainstream accounting is so attached to numbers, even though accounting is a discipline and practice that is influenced by its environment, after accounting is influenced then accounting again affects its environment (Triyuwono, 2015). Therefore, when accounting grows in a capitalist environment, the values in accounting will also be capitalist. As a result, the network of capitalist power shackles humans to always practice it.

Profit orientation is one of the thoughts of modern accounting and part of the characteristics of capitalism. Determination of the method that is widely practiced in the business world is a capitalist method that uses a lot of selfish and materialistic attitudes in its implementation. Triyuwono (2015) explains that the separation between the material and non-material sides provides an imbalance. The determination of the selling price which is dominated by the material side creates inequality. The selling price practiced by the conventional system is only profit-oriented (Amaliah, 2014). The conventional system emphasizes that accounting is a value-free science and practice, so the selling price is also included in it. Triyuwono (2015: 114) concludes the statement put forward by Capra (1997) that accounting science is not value-free. This is because the first in the accountant will not be able to eliminate the "value" be it knowledge, experience, and community values, the second reality being studied is a social reality created from social interaction. And there is no value-free science as long as humans are involved in its construction. It can be concluded that the selling price is a science and practice that is very closely related to the value in it.

Accounting which is a science and practice that comes from concepts, explanations, and reasoning that is comprehensive so as to produce an understanding of accounting. Gray (1988) in his research explains that accounting practices are also created from the environmental values contained in it, in this case the country that uses the accounting system. To develop a system that is appropriate to the actual conditions in an area, it is better not only to understand the accounting practices that are being used. Cultural values that have long existed in an area will also have an influence on the accounting system used. Gray (1988) explained how Japan was able to exist with an accounting system that also attached cultural values as the identity of the country of the rising sun.

Culture is born from habits created from a region. Where subjectivity is inherent in these cultural values. Koejaraningrat (1990: 181) gives a difference between the words culture and culture, culture means the power of the mind in the form of creativity, intention and taste, while culture means the result of creativity, initiative, and taste. However, Koetjaraningrat (1990: 181) states that the words culture and culture have the same meaning. It can be concluded that culture is a way of life that is obeyed together in a community group.

The reality of Indonesian society which is very closely related to cultural values, of course, also affects the lifestyle of its people. This culture also affects the way people carry out their social activities. This also affects the way of trading which includes living cultural values. Jual kase-kase is one of the sales practices carried out by traditional Banggai traders. Jual kase-kase is a selling practice, where in selling the sellers voluntarily give extras or bonuses to buyers sincerely. Jual kase-kase is a term that comes without being agreed upon, but becomes a habit for a group of traders. The traditional market in Banggai Regency is not all traders use the practice of Jual kase-kase but only a few traders are members of a group. Where they still adhere to the cultural values inherent in their daily activities.

This research was conducted referring to Amaliah \& Sugianto's (2018) research on "The Concept of Betawian Selling Price in Si Pitung's Frame". Where in the study found that the concept of the selling price of si pitung provides an advantage for business actors successfully. The value-based phenomenology of si pitung is used to achieve the objectives of this study. So a price concept that not only gets material benefits but also gets non-material benefits. The cultural diversity that exists in Indonesia is one of the factors that researchers conduct research on the meaning of the selling price of jual kase-kase by groups of traditional traders.

This study aims to reveal the meaning of selling prices in the practice of selling cases from the perspective of traditional traders. The difference of this research from previous studies lies in the sales practices carried out by groups of traditional traders. Where, they do not act as distributors of goods, but they sell goods that are processed themselves. This study uses an ethnomethodology approach to reveal the meaning of selling from the practice of jual kase-kase carried out by a group of traditional traders. Still exist without participating too much with the changes that are around them, and still holding fast to the cultural values that make them special as a community among traditional traders.

\section{Research and Methodology}

This study uses an interpretive paradigm and ethnomethodology as an approach in this study. The interpretive paradigm was chosen because it has the main agenda for the search for meaning from everyday experiences (Amaliah 2014). An interpretive paradigm that has the aim of interpreting what is behind the events, the background of the human thought involved in it, and how humans put meaning in the events that occur (Audifax 2008: 29), where it is emphasized that the basic research is carried out to understand social reality in what way. existence (Ludigdo 2007: 68). Using the interpretive paradigm, the researcher hopes to be able to reveal the ways 
in which the actors set the selling price which is their daily activity. The results in this study, of course, cannot be generalized because each practice has its own uniqueness which is influenced by each social situation.

The ethnomethodology used in this study aims to understand the practice of determining the selling price of "jual kase-kase" and to find the meaning behind the determination of the selling price. Ethnomethodology is used with the aim of capturing the reality of accounting practice in a thoroughly researched society according to the context. The ethnomethodological approach focuses on how humans create and understand everyday life in their lives. Therefore, ethnomethodology focuses on routine activities carried out by group members (Kamayanti. 2016: 133). Thus ethnomethodology explains about each individual in carrying out activities continuously but does not question why it can happen.

Ethnomethodology has several stages in analyzing data. In this study there are three stages, namely the first stage of indexicality analysis. Indexicality is used with the opinion that social activities are formed in everyday language, where the language is attached to words and circumstances that take place. In this study, indexicality was obtained from traditional traders about how they interpret the selling price they provide. The process of participatory observation and unstructured interviews were carried out to obtain data. The second stage is reflexivity analysis. This analysis was carried out after the researchers observed and found the expression of indexicality. In this study, reflexivity analysis is devoted to revealing things both implied and explicit from traditional traders in interpreting the selling prices they set. When conducting reflexivity analysis, the researcher also paid attention to body cues made by actors outside of their awareness, as well as the involvement between the meaning of one event and another. The third stage is contextual action analysis. In this analysis, researchers reveal practical daily activities that can be known and reported. In this stage, the researcher is directly involved in participatory observation, making it easier to connect indexicality with reflexivity. In the study, the researchers conducted observations and interviews directly with several informants. Informants in this study were divided into two, namely main informants and supporting informants. Informants in this study are presented in the table below;

Table 1: The list of informants

\begin{tabular}{llll}
\hline $\mathbf{N o}$ & Name & Age & Information \\
\hline $\mathbf{1}$ & Masipa / Tata Ipa & 55 & Vegetable seller \\
\hline $\mathbf{2}$ & Amrin & 52 & Fisherman/Ship owner/Fish seller \\
\hline $\mathbf{3}$ & Jumrah & 40 & Fish seller \\
\hline $\mathbf{4}$ & Adi Burhanudin & 55 & Banggai Community Leader \\
\hline $\mathbf{5}$ & Nurmawati & 35 & Academics \\
\hline
\end{tabular}

The list of informants contained in the table above, it can be seen that these informants have different backgrounds. The main informants consist of traditional traders, as well as supporting informants consisting of community leaders and academics who understand the sales practices carried out.

\section{Discussion}

Culture cannot be separated from human life, because humans are both creators and users of culture itself. Cultural values in the proud society are known as the Montolutusan culture or the value of brotherhood which is believed not only to come from the same lineage but also on the basis of humanity. Dormeier (1947) in his book Banggai Customary Law explains that montolutusan is a social order that shapes the character of society, where they feel connected to each other and participate in one unit. Their social relationship is formed without regard to the descendant relationship that comes from one ancestor. In addition to cultural values, spiritual values also influence the character of every society. Belief in one God and submission to all of God's decrees is an inherent character in people's daily lives. The values of brotherhood and spiritual values in which there is also a sense of help and affection also influence traders in sales activities which are reflected in the practice of jual kase-kase.

The practice of jual kase-kase is generally carried out by traditional Banggai traders. Where in these sales practices they sell their own farm produce or fish catch. The basic difference between Banggai traditional traders and other traders is that traditional traders do not act as intermediaries between producers and consumers and do not buy goods to be sold. At first the traders sold from house to house carrying merchandise using baskets. Sales are carried out by barter system, where traders bring their goods to people's homes and let them vote. After that, the goods sold will be handed over to the buyer, and the buyer pays with the goods owned to make an agreement to exchange goods. In selling there is no specific measure for the amount of merchandise that will be given to the buyer, all purely from an agreement between the seller and the buyer. It is from this practice that the terms of selling cases are indirectly mutually agreed upon. Cases is a colloquial language which means to give voluntarily. The beginning of the practice of selling cases is reflected in Adi Burhanudin's statement;

"Since long ago, the way sellers transact started with barter. Buyer and seller agree on the goods to be exchanged. But the traders when selling do not give a measure of the number of goods sold, later when the buyer finishes choosing the desired item, the buyer 
will notify the merchant of what type of goods the buyer will give. When the goods provided by the buyer are deemed necessary, the merchant will agree to the transaction."

The statement above explains that the practice of selling cases that began with a barter system is based on the fulfillment of the needs of each party. In barter activities carried out by traders, they do not provide a measure of the amount of goods exchanged for other goods. So in this case the fulfillment of each need is more important than the amount of profit to be obtained.

Over time, house-to-house sales began to be abandoned and traders began selling in the market. The change in the place of sale is one of the reasons the barter system is no longer used. The use of money in transactions requires traders to give a value or price to the goods to be sold. This is explained by Jumrah as follows;

"We give prices on merchandise starting from the difficulty of finding buyers who want to barter. After that, because the government advised us to sell in the market, we made us follow the same conditions as other people to give prices."

From the statement above, it means that every change will definitely happen. Thus as humans must participate in these changes. To exist and participate in change, one must learn and adapt to new environmental conditions.

\section{Discussion (Ator Bae) Begins Sales Activities}

The initial stage before starting sales activities carried out by traders is ator bae. Ator bae or deliberation is done by traders to discuss the highest and lowest prices for each of their merchandise. Ator bae was first carried out with the aim of providing traders with an understanding of the sales activities carried out in the market, because traders used to be used to selling from house to house and by berter. Changes in the place and way of trading indirectly give traders confusion. This made one of the traders who first sold in the market took the initiative to conduct deliberations, as a learning tool as well as a means to ask about the difficulties experienced by traders who were new to selling in the market and old traders. This was explained by Adi Burhanudin as a community leader who pays attention to the development of traders when selling;

"Ator bae was first coined by Mr. Amrin, he is a trader who has been selling in the market. When traders are asked to sell in the market. he said he noticed that the traders were a little confused in giving prices, and there were also those who felt confused about the situation of selling in a different market from the way they sold when selling from house to house. This situation moved him to invite these traders to talk to ask questions that confused them. After a lot of talking, he saw that there was a change in the merchants' way of selling. Finally ator bae continues until now"

While the conversation was going on. Before entering the price setting, traders discussed the conditions experienced in the previous days and the obstacles experienced today in carrying out selling activities. In addition, this discussion also discusses the size of each item that will be given to the buyer. If there is a trader who does not meet the dose, then another trader who has an excess will help provide free the needed items. Not only that, this discussion process also makes it easy for traders who come from the same residential location as other traders to get to the market. The convenience that exists is the reduction in transportation costs that must be incurred because, in this discussion, this discussion will provide a way out which in turn costs less. Mr. Amrin explained the discussion process as follows:

"We started this conversation with bismillah, so that the activities carried out were blessed by Allah, given instructions for a good solution for all our affairs. After that, we had a light conversation, asking how the sales activity was in the past week, what the obstacles were, who sold full time for a week, and who couldn't sell in full and what were the obstacles."

From the ator bae or deliberation process, it provides an overview of the selling price of the selling cases carried out by the traders. Where in the discussion carried out is not limited to determining the price that will provide benefits, but more emphasis on providing convenience when making sales. And with the ator bae process, it is able to bring the relationship between sellers closer, so that the sense of brotherhood is increasingly felt even in economic activities.

Competition that often occurs in the business world, especially trade, is trying to be minimized by the role of traditional traders. Therefore, the discussion was carried out with the aim that trading activities between one trader and another did not have price competition. This is in contrast to modern accounting pricing methods, where competitors are used as benchmarks as determinants in the selling price of the product. In the practice of "selling cases", it begins with a discussion so that each trader understands the needs of other traders. Resulting in mutual help to fellow traders and avoiding price competition which will have a negative impact.

\section{Price in a Brotherly Relationship}

The discussion process has been carried out by fellow traders and the traders are ready to carry out their selling activities. In this activity, researchers can find the meaning of the selling price given by traders in the practice of jual kase-kase. Wider interaction by traders, either to fellow traders or to buyers. In the interactions that are carried out either to fellow traders or to buyers, they build a relationship. In this relationship, the value of the material is not the main goal of creating a good relationship. This is also a shaper of the selling price given by traders. Where a material advantage that is the goal for modern economic activity is not the main goal for traditional economic actors, in this case traditional traders. 
Prices given by traders are strongly influenced by existing interactions. The interaction is created from bargains made by buyers and traders, or just a small talk between the two. The familiarity created will affect the price given and the buyer will receive more excess goods. Not only that, in sales activities, traders who have problems in fulfilling merchandise will be given voluntary assistance by other traders. It is intended that traders who have difficulties can still carry out sales activities. Mrs. Jumrah explained the assistance provided by other traders, so that she could still sell;

"When selling this fish, I don't have to pay in advance to get the fish to be sold. But I was allowed to make payment after the fish was sold out. For the recording of accounts payable, Mr. Amrin did not record it because he believed that I would pay according to the amount that had to be paid. This makes me feel that I must always pay my bills on time, so that good relationships are always created. Moreover, the number of fish that Mr. Amrin always has is more than the mutually agreed amount. This makes it easier for me to give bonuses to buyers."

The statement above illustrates that transactions made by fellow traders based on a sense of trust are an important factor in conducting trading activities. Payments made after the sales process has been completed reflect the special relationship created so as to provide convenience. With this relationship, it will affect the continuity of the business being carried out. This is in accordance with Amaliah's statement (2014) in his research stating that the relationships that exist in the community become a strategy in building and maintaining the sustainability of a business from day to day. In addition to fellow sellers, special relationships are also carried out with buyers. Bargaining is not often the case by buyers and sellers because the prices given are relatively cheap compared to other sellers. In addition to maintaining the quality of goods, it has given the trust of buyers and continues to carry out buying and selling activities with traders. This is explained by Mrs. Nurmawati as follows:

"They sell with small capital and only sell the vegetables and spices they grow. But their hands are light in giving bonuses to buyers even though if I am a buyer the price given is cheap compared to other sellers. For sellers who think about profit in material value, they must choose one of them, either by giving a low price or giving a little bonus."

"The price and the bonus that the buyer gets can be called the price of a friend. Why? because the seller who applies the jual kasekase does not distinguish who the buyer is. Luwuk is an area with many immigrants. But in transacting even giving, say "bonus" the traders never make a difference. Even though it's very clear in terms of language, speaking accent. That way also creates a bond between the seller and the buyer, the result is a permanent buyer. Can sell wares."

Prices are generally used as a strategy in marketing goods to gain profits for a business. However, price can also be used as a form to strengthen social relations. In the statement above, it can be illustrated that in setting prices the traders present the values of brotherhood in it. Where in these values the sense of togetherness becomes more dominant than the desire to achieve a lot of profit.

The determination of the selling price given by traders, either to fellow traders or to buyers, has the meaning of creating a social relationship that is not only oriented to profit and loss. The practice of "selling cases" carried out by traditional traders is surrounded by brotherly values that are present from the individual characteristics of the traders. In running a business, the character of a trader becomes one of the supporting factors in the continuity of his business, which will provide a long-term relationship between fellow sellers and between buyers. Thus, the determination of the value of an item presents material benefits and non-material benefits.

\section{Selling Price in Sincerity and Honesty}

Sincerity and honesty that take part in determining the selling price given by traders cannot be separated from the traders' belief in God Almighty. Therefore, forming the character of traders in carrying out social activities. This belief presents spiritual values, namely sincerity and honesty. Economic activities that include sincerity and honesty will make the continuity of the business run for a long time, especially trading activities. This is due to the interaction between the seller and the buyer which will give the buyer a sense of trust in the seller. The seller's honesty can be seen from the conversation between Ms. Masipa and the buyer below;

“This tomato costs 6,000/kg, this one 8,000/kg” (Trader)

"Why are the prices different?" (Buyer)

"Because the 6,000 that were sold yesterday and the 8,000 that were just harvested but both are in good condition, not rotten" (Traders)

"I bought the 8.000" (Buyer)

"Please choose yourself, after that I will weigh it" (Trader)

"good, thank you" (buyer)

From the conversation above, it can be seen that the merchant honestly informs the condition of the goods being sold, and gives the buyer the freedom to choose the goods that are good according to him. This causes the presence of a sense of trust from the buyer to the seller, as well as a sense of justice because of the sacrifices made by the buyer in accordance with the quality of the goods received. Buyer's trust and satisfaction is what makes a business last a long time. In addition to honesty, traditional traders also have a high sense of sincerity and empathy for their environment. Understanding the conditions of buyers and giving bonuses voluntarily 
characterizes traders in selling activities. The sensitivity of traders when dealing with buyers who are in unfavorable conditions, as well as putting aside material gains can be seen from the statement below;

"The previous buyer, twice passed the shop. So I felt that he really wanted to buy but was short on money. Therefore, I give the price that is usually paid by the buyer with a larger number of goods. Because not everyone can meet the needs according to the standards that others provide. Sometimes we as sellers have to take the initiative to make it easier for buyers who are experiencing economic difficulties." (Amrin)

From the conversation above, it can be seen how traders set prices based on sincerity to provide convenience for buyers who are in difficult circumstances. Sensitivity to the surrounding conditions helps every trader in conducting economic transactions. The merchant still gets money for the goods sold, but the value of the goods sold is adjusted to the circumstances of the buyer. Thus, the agreement between the seller and the buyer is still carried out, and the satisfaction of the merchant and the happiness of the buyer can be felt in one sale and purchase transaction. Existing satisfaction arises from a sense of humanity because it is able to facilitate other human affairs, as well as satisfaction and gratitude from buyers because traders are appreciative by accepting money for goods purchased even though the value given is not what it should be.

The presence of honesty and sincerity in trading activities, price fixing given to buyer traders illustrates that material profit is not the main goal of the way of trading by traditional traders. Keeping buyers trust in the quality of the goods being sold is an important factor in trading. Small profits but bring long-term trust from buyers are a way for traders to stay involved in the business world.

\section{Conclusion}

The practice of "selling cases" is a sales practice carried out by traditional traders. In "selling cases" the traders interpret the selling price they provide based on the relationship. Starting from price fixing, the traders want to reduce price competition which they think will have a bad impact on the relationship between traders, so before starting the sale the traders have a discussion. The price of the relationship given by the traders gets a more complete advantage, namely material benefits and non-material benefits. The price of this relationship cannot be separated from the character of the traders themselves, where cultural values are inherent in the individual characters of traders. The advantage of pricing this relationship is not only seen from the nominal material obtained but also from social and spiritual relations from traders. Community relations provide benefits to the sustainability of the business being carried out and the material benefits obtained. The spiritual advantage of traders can be seen from the sincerity of heart when running a business, because the sales made are not only world-oriented but far more than that. So that the selling price of the practice of "selling cases" practiced by traditional traders, provides a new perspective. Where in determining the selling price, material and non-material profits are combined into one unified whole.

The results of this study provide several implications. First, the theoretical implications, the results of the study reveal the meaning of the selling price in which local cultural values are reflected in the brotherly relationship that is built both among sellers and buyers, as well as the presence of spiritual values in the given selling price. The selling price given by the trader provides an understanding that in setting the price it is not only about studying the profits obtained. The meaning of the selling price combined between accounting knowledge and the culture that is carried out can produce accounting that has the value of togetherness as fellow human beings and submission to God.

Second, the practical implications. The existence of cultural values and spiritual values that participate in the meaning of the selling price given by traders, can provide an overview that can be applied in determining the selling price. So that the price given is not only focused on achieving material benefits but also achieving non-material benefits. So that as a human being, we are able to benefit not only in this world but also in the hereafter.

The results in this study provide an understanding of the reality of the practice of setting selling prices in which there is a meaning of pricing by a community. The community includes several products that are sold. So this research provides space for further research to focus on one type of product in order to be able to examine it more deeply.

\section{References}

Akbarina, F. (2018). Pengantar Bisnis: Pengantar Bisnis. Malang: UPT Percetakan dan Penerbitan Polinema.

Amaliah, T. H. (2014). Konsep Penetapan Harga Jual Papalele dalam Lingkup Nilai- Nilai Budaya Masyarakat Maluku. Disertasi Tidak Dipublikasikan, Program Pascasarjana, Universitas Brawijaya Malang.

Amaliah, T. H. (2016). Nilai-nilai budaya tri hita karana dalam penetapan harga jual. Jurnal Akuntansi Multiparadigma, (6), 189206.

Amaliah, T. H., \& Sugianto. (2018). Konsep harga jual betawian dalam bingkai si pitung. Jurnal Akuntansi Multiparadigma, (6), $20-37$.

Audifax. (2008). Re-search: Sebuah Pengantar untuk “Mencari-Ulang” Metode Penelitian dalam Psikologi. Yogyakarta: Jalasutra. Dormeier, J. . (1947). Hukum Adat Banggai. In Banggaisch adatrecht.

Grey, S. J. (1988). Towards a Theory of Cultural Influence on the Development of Accounting Systems Internationally. ABACUS, 24(I), 1-15. 
Hardesty, D. M., Bearden, W. O., Haws, K. L., \& Kidwell, B. (2012). Enhancing perceptions of price - value associated with pricematching guarantees. Journal of Business Research, 65(8), 1096-1101. https://doi.org/10.1016/j.jbusres.2011.08.024

Hinterhuber, A. (2008). Customer value-based pricing strategies: why companies resist. 29(4), 41-50. https://doi.org/10.1108/02756660810887079

Kamayanti, A. (2016). Metodoligi Penelitian Kualitatif Akuntansi: Pengantar Religiositas Keilmuan. Malang: Yayasan Rumah Peneleh.

Koentjaraningrat. (1996). No Pengantar Antropologi I (Cetakan Pe). Jakarta: PT Rineka Cipta.

Ludigdo, U. (2007). Paradoks Etika Akuntan. Yogyakarta: Pustaka Pelajar.

Mulyadi. (2001). Akuntansi Manajemen Konsep, Manfaat dan Rekayasa. Jakarta: Salemba Empat.

Pellinen, J. (2003). Making price decisions in tourism enterprises. 22, 217-235. https://doi.org/10.1016/S0278-4319(03)00019-7

Sardjono, S. (2017). Ekonomi Mikro - Teori Dan Aplikasi. Yogyakarta: Penerbit Andi.

Triyuwono, I. (2015). Akuntansi Syariah: Perspektif, Metodologi, Dan Teori (Ke 2). Jakarta: Rajawali Pers.

Winardi. (1987). Pengantar Ekonomi Mikro (Teori Harga). Bandung: Penerbit Alumni.

Witjaksono, A. (2013). Akuntansi Biaya. Yogyakarta: Graha Ilmu.

Publisher's Note: SSBFNET stays neutral with regard to jurisdictional claims in published maps and institutional affiliations.

\section{(c) (1)}

(C) 2021 by the authors. Licensee SSBFNET, Istanbul, Turkey. This article is an open access article distributed under the terms and conditions of the Creative Commons Attribution (CC BY) license (http://creativecommons.org/licenses/by/4.0/).

International Journal of Research in Business and Social Science (2147-4478) by SSBFNET is licensed under a Creative Commons Attribution 4.0 International License. 